\title{
On Studying the Construction of Application-Oriented Universities from Perspective of Industry-University-Research(IUR)
}

\author{
Yan Jiang ${ }^{1, a}$, Ruigang Ren ${ }^{2, b}$ \\ ${ }^{1}$ Nanchang Institute of Science and Technology; NanChang,330108,China \\ ${ }^{2}$ Jiangxi Institute of Fashion Technology, NanChang,330201,China \\ aemail:63448054@qq.com, bemail: 39084934@qq.com
}

Keywords: Industry-University-Research, Education resources, Practice; teaching mode

\begin{abstract}
Under perspective of Industry-University-Research, colleges and universities make full use of educational environments such as their institutions, enterprises, etc., educational resources, and different strengths of social system to absorb the merits of each other, aiming to cultivating students' learning, innovation and practical ability. Transforming knowledge-centered teaching mode into experience-centered learning mode which combined theory and practice together, application-oriented universities would produce more practical talents to enterprises and society, so as to realize its values. This passage has discussed the significance of IUR Cooperation Education in the construction of application-oriented universities, problems existing in the construction of application-oriented universities under the perspective of IUR and three constructing methods of application-oriented universities under perspective of IUR, aiming to pave the way for construction and development of universities under perspective of IUR.
\end{abstract}

\section{The Significance of IUR Cooperation Education in the Construction of Application-oriented Universities}

\section{It's an important way to improve college students' comprehensive ability}

Through the cooperation between industry, university and research institutions, the IUR Cooperation Education, taking respective advantages, formed an advanced system of integration of research, production and development, and reflected comprehensive advantages during its operation. At present, in the situation of continuous development, Chinese application-oriented universities put forward higher requirements on the goal of talent development, requiring that contemporary college students should not only master the knowledge from school, but also put it into practice of real life; that not only have profound knowledge, but also have practical ability; that not only be able to find problems, but also be able to solve practical problems.

From the social development situation, the construction and development of Chinese characteristic socialism can't do without colleges and great hope on college students. Colleges and universities are important bases of training talent needed by society. IUR Cooperation Education's getting into application-oriented universities can cultivate students' practical and thinking ability in wide ways and many layers, and train college students' innovation ability and practice the spirit of enterprise, developing fully in virtue, intelligence, physical culture, aesthetics and labor. In a word, IUR Cooperation Education in application-oriented universities can integrate resources of colleges and local area, adopting the University Science Park model of "one college, many schools" to improve college students' comprehensive ability continuously.

It's the developmental needs of application-oriented universities.

Application-oriented universities are important area to cultivate large quantities of outstanding talents, which shoulder important historical responsibility of whether college students can become talents necessary for social development or not; which is a sign whether Chinese colleges and universities construction fit the trend of social trend or not; which is also the powerful backing of the continuous development of Chinese socialism.

In the situation of continuous innovation and development of Chinese socialism, IUR Cooperation Education can make the teaching content, curriculum and off-campus practice of 
application-oriented universities more applicable for the social developmental needs, so as to improve education quality largely, and win the national and social praise. Colleges and universities' making full use of the cooperation of IUR institutions would help students adapt to the needs and development of enterprises as quick as possible when they are in society. Meanwhile, in the interaction process of teachers' imparting knowledge and student' accepting knowledge, both students' ability and teachers' teaching level would grow, as well as school-running and teaching level of application-oriented universities efficiently.

\section{It's Helpful to Improve Students' Enthusiasm Application-Oriented Universities.}

"People-oriented" is an important strategy for the development of Chinese socialism. Education in universities gradually construct a teaching model of "student-centered", which played a principle role greatly. Simply speaking, it demands students' active learning, instead of passive learning. The aim of IUR Cooperation Education is to stimulate students' enthusiasm and initiative from various aspects, making students find their values in social development by means of personal practice and experience, finding their shortcomings and deficient ability in their learning process, and stimulating students' curiosity constantly. The IUR Cooperation Education mobilizes students' learning motivation and initiative from all aspects of universities, enterprises and society, and transforms passive learning into active learning indeed, so as to realize principle of "people oriented" and efficiently enhance application-oriented universities' ability to cultivated completely developed students.

\section{Problems Existing in the Construction of Application-Oriented Universities under the Perspective of IUR}

\section{Single Selection Form of Teachers, and Lacking of "Dual-mode" Teachers}

At present, most teachers in Chinese application-oriented universities have a higher education and profound knowledge, which plays an imperative role in bettering college students' knowledge and deepen their professional cognition. Under the perspective of IUR, application-oriented universities' tasks proposed by society are not only the improvement of knowledge, but also improving students' innovation and practical ability during school days, so as to make graduates adapt to social development and their own jobs quickly once they step into the society.

Most application-oriented universities select teachers by considering their qualifications and educational background, in which little part-time faculties serve teaching some courses, and some of this part-time teachers are from society specializing in one particular profession. For this kind of teachers, they have deeper understanding of their own profession, and the understanding does not just confined in knowledge, but know enough about the specific requirements of profession and ability from society. The lacking of "dual-mode" teachers, who have both profound knowledge and professional practical ability, and the lacking of faculty construction is the main problem of Chinese application-oriented universities, and it is the obstacle of the development of IUR Cooperation Education.

\section{Deficiency of the Combined Foundation between Universities and Enterprise, and of Capital Investment of IUR}

The essence of IUR Cooperation Education is to combine universities and enterprises together effectively and to promote them work together. The ultimate purpose of students' further education in application-oriented universities is to make them adapt to the developmental trend of enterprises, and cultivate their ability of realizing self-own value and social value in enterprises. In the long term, the two social systems, universities and enterprises, are closely linked with each other. But most of application-oriented universities workers ignored the linkage, and take advantage of test scores and graduation certification to measure students' learning effect and teachers' teaching effect. For a long time, people thought that outstanding students are labeled with high scores and credits. The condition makes universities far behind society, and the disconnect would definitely contribute to the growing gap between the target students cultivating by universities and the needed talents of enterprises.

Besides, IUR Cooperation Education lays emphasis on the combination of learning and practice, 
which needs increasing investment of human resources and material resources from universities. For now, owing to immaturity of IUR Cooperation Education, the emphasis of investment of universities is still on improving performance and teaching equipment, which makes the deficiency of investment of IUR Cooperation Education, and then cannot put it into the major developmental projects of application-oriented universities.

\section{Lacking of Deep Recognition of IUR Cooperation Education and Sufficient Cooperation}

In IUR Cooperation Education, good results can't do without any efforts and coordination. Enterprises, as one of the major parts in IUR Cooperation Education, is the requester of application-oriented universities' cultivated talents. Under the perspective of IUR, enterprises hope to join in the process of training talents and instruct teachers' teaching and students' learning process in the right direction, so as to lay a solid foundation of their talents selection, speed up the transformation of scientific and technological achievements, and enhance the competitiveness of enterprises in the market. However, only when universities cooperate better with enterprises and work out better plans, can they better achieve their developmental goals.

At present, the cooperation between universities and enterprises is mainly seen before application-oriented university students' graduate. Students can work as interns in cooperative enterprises, but receive no attention. Enterprises thought taking interns seriously would increase their cost, no matter on human resources or on material resources. Shortage of internship, no serious guidance from professional seniors, and unable to undertake working tasks are main condition of internship cooperation between application-oriented universities and enterprises at present. This verbally IUR Cooperation Education doesn't work effectively or take any advantages. Considering of interns' safety and ability problems, enterprises do not want to hire undergraduates, or many of them even prefer to employ well-experienced workers. However, from the long-term interests, the IUR Cooperation Education is difficult to carry on, which would cause the disjoint of needed talents and then a growing number of college students would be difficult to adapt to their posts.

\section{Reforming Method of Application-oriented Undergraduate Universities Construction from the Perspective of IUR Cooperation}

\section{Enriching the Forms of Cooperation of On-Campus Training Bases with Off-Campus Training Enterprises}

In terms of teaching achievement of application-oriented undergraduate universities in our country, there has been a relatively large breakthrough in the level of college education and student's academic achievements, and basically they reach the level required by national education. From the perspective of IUR cooperation, college students are required to possess not only encyclopedic knowledge but also some skills acquired in society. They cannot be oblivious of the outside world and just focus on study. On the contrary, they need to move out of campus and step into society. On campus, some basic practice skills of students can be cultivated. In order to reach a better effect, universities need to establish high-standard and high-tech training base on campus by means of increasing investment in the aspect of cultivating students so that hands-on skill and thinking ability can be improved and student's innovative awareness can be cultivated. For instance, modern science and technology can be used to build virtual market and virtual logistics. Therefore, student's knowledge acquiring in class is extended and furthered, making a better combination of theory learning and practice. As for some students who cannot conduct some simulated trainings on campus, universities should negotiate with some off-campus enterprises and cooperate with them, thus enabling students to adapt to the environment of enterprises and society, gain a good command of required skills and lay a solid foundation for their adjusting to jobs after graduation. Enterprises also should coordinate actively with universities in order to gain mutual benefit and promote IUR cooperative education.

\section{Diversifying Forms of Cooperation and Increasing Investment in IUR Cooperation}

According to IUR cooperation, application-oriented undergraduate universities should attach importance to IUR cooperative education and make it a strategic goal for long-term development. Cooperation is the key to developing IUR cooperative education. Colleges and enterprises should 
explore and conduct diversified cooperation. For example, Colleges and enterprises can reach intent of long-term cooperation. On one hand, colleges can recommend some excellent talents for cooperative enterprises, thus providing personnel support for development of enterprises. On the other hand, enterprises should also provide colleges with enough learning and practice space to make sure that students can get a quick and deep understanding of abilities and skills required by their majors during their college study and provide support for cultivating more talents who are suitable for the development of their enterprises. In this way, colleges have a clearer purpose and save more time in the process of cultivating excellent and all-round talents. To make common progress, both enterprises and universities should attach great importance to IUR cooperative education by helping each other. Although there is no property relation between colleges and enterprises, enterprises can be involved in teaching process. Therefore, they can talk over founding branches of colleges which aim to develop student's abilities to practice and innovate.

Besides, a large amount of money should be invested to promote IUR cooperation, including capital for introducing talents, namely, double-position teachers, capital for cooperation with enterprises and capital invested in training bases and self-established industry. Colleges should make full use of these capital and training bases, get rid of monotonous teaching mode and cooperate with enterprises to cultivate more excellent students for socialist construction.

\section{Forming a Team of Excellent Teachers and Establishing the System of Leader Group of IUR Cooperation}

In light of IUR cooperation, application-oriented undergraduate universities need to establish a perfect teaching system in academic research. More importantly, they should make teachers aware that the combination of theory and practice should be considered as the primary educational goal. Therefore, first of all, a group of excellent teachers should be cultivated to further student's understanding of this kind of education mode and boost IUR cooperation. For example, some leaders in universities can assign teachers to further education on a regular basis, and attend more lectures so that teachers are able to gain a real understanding of society and enterprise development. In addition, teachers' ability to teach can be improved gradually and their awareness of IUR cooperation also can be raised. And meanwhile students may be influenced by their teachers.

To promote the cooperation industry university and research, operational system of leading groups needs to be perfected and more kinds of practice activities can be conducted. The system of academic test should be improved, which means that students' enthusiasm and initiative should be included in student's comprehensive assessment in order to enable students to put a heavier emphasis on IUR cooperative education. The leading groups of IUR cooperation in colleges should follow this teaching mode, formulate assessment standard for teaching and research according to the development situation of colleges themselves and encourage teachers to go down to the grass roots and enterprises and receive tasks such as consultation, training, etc., thus forming a close association among teaching and research, society and demands of enterprises and providing more help for developing talent-cultivating mode or strategy in application-oriented undergraduate universities.

\section{Enabling Students to Play Major Roles in IUR Cooperative Education}

The main purpose of cooperation or collaboration of universities with enterprises is to develop students' comprehensive ability so that they can adapt better themselves to social development and provide guarantee for their career. Therefore, student is the final aim of the whole process and the students' major roles in this process cannot be ignored. In general, the reason why students are involved in IUR cooperative education is that they can obtain more working skills and experience when knowing of future working environment earlier and seeking job opportunities in advance. Only when students' learning purpose and learning motivation are constantly achieved and enthusiasm for student's innovation and practice is improved can application-oriented undergraduate universities promote better education development from the perspective of IUR cooperation. Consequently, in terms of IUR cooperation, all organizations and individuals should put a heavy emphasis on student's learning objectives and learning interest.

For example, when selecting cooperative enterprises, colleges should take advice that most 
students provide, gain understanding of interests in practice in enterprises by means of questionnaire. Finally, factor of many aspects should be considered and try to cooperate with those enterprises which interests students, which helps to strengthen students' enthusiasm for training and research. Furthermore, during internship students should pay attention to the change of roles for pure relationship between teachers and students doesn't exist there any longer and every student has the same status as his or her teachers and seniors. The role of student is not observing others' operation any more but practicing and experiencing in person and communicating with teachers, seniors in order to make mutual progress during training, thus making teaching results more pragmatic.

\section{References}

[1] Xu Zhenghong, Providing IUR Cooperative Education and Cultivating Engineering-Research-oriented Biotechnology Talents [J], China Education of Light Industry, 2002 (2).

[2] Zhou Ji, Promoting Development in Contribution with the Aim of Service: Unswerving Take the Path of IUR Cooperation [J], China Higher Education, 2007.

[3] Tian Nailin, Problems in the Teaching Process of IUR Cooperative Education and Solutions [J], Journal of Chengde Petroleum College, 2006.

[4] Yang Chenguang, Fulfilling Innovative Potential in Practice [N] China Education Daily, 2007(11).

[5] Gu Weizhong, Liu Lan On Problems in IUR Cooperation and Its Policies [J], Journal of Beijing Institute of Machinery, 2006.

[6] Li Dasheng, IUR Cooperative Education and Cultivation of Innovative Talents [J], Higher Education Exploration, 2007 (5). 